\title{
Overexpression of hAPPswe Impairs Rewarded Alternation and Contextual Fear Conditioning in a Transgenic Mouse Model of Alzheimer's Disease
}

\author{
Kevin A. Corcoran, ${ }^{1}$ Ye Lu, ${ }^{3}$ R. Scott Turner,${ }^{2,3,4}$ and Stephen Maren ${ }^{1,2,5}$ \\ ${ }^{1}$ Department of Psychology, ${ }^{2}$ Neuroscience Program, and ${ }^{3}$ Department of Neurology, University of Michigan, Ann Arbor, Michigan 48109, USA; \\ ${ }^{4}$ Veterans Affairs Medical Center Geriatrics Research, Education, and Clinical Center, Ann Arbor, Michigan 48105, USA
}

\begin{abstract}
One of the hallmarks of the pathology in Alzheimer's disease is the deposition of amyloid plaques throughout the brain, especially within the hippocampus and amygdala. Transgenic mice that overexpress the Swedish mutation of human amyloid precursor protein (bAPPswe; Tg2576) show age-dependent memory deficits in hippocampus-dependent learning tasks. However, the performance of aged $\mathrm{Tg} 2576$ mice in amygdaladependent learning tasks has not been thoroughly assessed. We trained young (2-4 mo) and old (16-18 mo) Tg2576 and wild-type mice in a T-maze alternation task (hippocampus-dependent) and a Pavlovian fear-conditioning task (amygdala- and hippocampus-dependent). As previously reported, old Tg2576 mice showed impaired acquisition of rewarded alternation; none of these mice reached the criterion of at least five out of six correct responses over three consecutive days. In contrast, old $\mathrm{Tg} 2576$ mice showed normal levels of conditional freezing to an auditory conditional stimulus (CS) and acquired a contextual discrimination normally. However, when the salience of the fear-conditioning context was decreased, old (12-14 mo) $\mathrm{Tg} 2576$ mice were impaired at acquiring fear to the conditioning context, but not to the tone CS. Histological examination of a subset of the mice verified the existence of amyloid plaques in the cortex, hippocampus, and amygdala of old, but not young, Tg2576 mice. Hence, learning and memory deficits in old Tg2576 mice are limited to hippocampus-dependent tasks, despite widespread amyloid deposition in cortex, hippocampus, and amygdala.
\end{abstract}

The development of transgenic (Tg) mice that overexpress the Swedish mutation of human amyloid precursor protein (bAPPswe; Tg2576; Hsiao et al. 1996) has provided a springboard for research into the cellular and molecular bases and behavioral sequelae of Alzheimer's disease (AD). Of the many neuropathologies evident in $\mathrm{AD}$, amyloid plaques derived from deposited amyloid $\beta$-peptide $(\mathrm{A} \beta)$ and neurofibrillary tangles have received a great deal of attention. The former may be responsible for initiating a biochemical cascade that leads to cognitive decline in AD patients (Näslund et al. 2000; Selkoe 1998, 2000, 2001; Steinhilb et al. 2001). Amyloid plaques in hAPPswe mouse brain, like those seen in human $\mathrm{AD}$ patients, lead to activated microglia (Frautschy et al. 1998), oxidative stress (Pappolla et al. 1998; Smith et al. 1998; Matsuoka et al. 2001), and alterations in neurotransmitter systems (Tomidokoro et al. 2000); all are potential mechanisms by which amyloid deposition disrupts normal neural function.

Distribution of amyloid plaques is not uniform throughout the brains of $\operatorname{Tg} 2576$ mice (Chapman et al. 2001);

${ }^{5}$ Corresponding author.

E-MAIL maren@umich.edu; FAX (734) 763-7480.

Article and publication are at http://www.learnmem.org/cgi/doi/ $10.1101 / \mathrm{lm} .51002$ rather, amyloid deposition is densely concentrated in the cortex, hippocampus, and amygdala. This is similar to the nature (Terai et al. 2001) and pattern (Hopper and Vogel 1976; Hyman et al. 1990; Price et al. 1998; Chapman et al. 2001) of the neuropathology seen in human AD patients. The anatomy of amyloid deposition in $\mathrm{Tg} 2576$ mice indicates that these mice might be deficient in forms of learning that depend on the hippocampus and amygdala, for example (Hyman et al. 1990). Consistent with this hypothesis, learning and memory deficits have been reported in several hippocampus-dependent learning paradigms in Tg2576 mice. In most cases, these deficits are age-dependent and are only shown in senescent mice (Hsiao et al. 1996; Chapman et al. 1999; Morgan et al. 2000). Although aged Tg2576 mice are impaired at learning several tasks that depend on the hippocampus, the performance of these mice on tasks requiring an intact amygdala has not been thoroughly established (Ashe 2001).

To address this issue, we trained wild-type and $\mathrm{Tg} 2576$ mice in a Pavlovian fear-conditioning paradigm that is both hippocampus- and amygdala-dependent (Kim and Fanselow 1992; Phillips and LeDoux 1992; Maren and Fanselow 1996; Maren et al. 1998; Maren 1999). We hypothesized that old Tg2576 mice would be deficient compared with old wildtype and young mice in learning to fear a tone conditional

LEARNING \& MEMORY 9:243-252 @ 2002 by Cold Spring Harbor Laboratory Press ISSN1072-0502/02 \$5.00

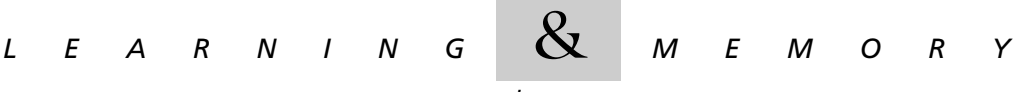

$$
\begin{aligned}
& \text { www.learnmem.org }
\end{aligned}
$$


A

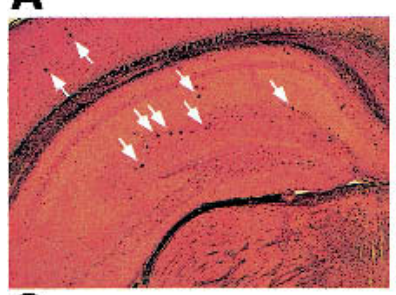

C

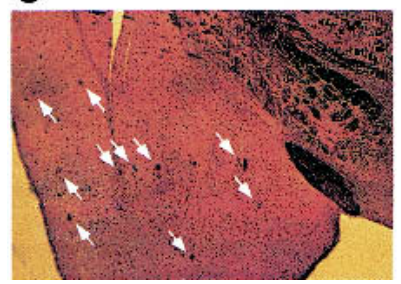

B

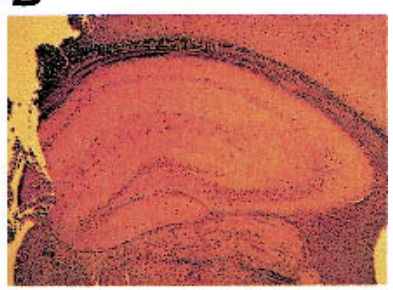

D

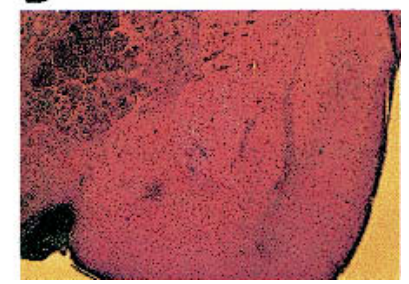

Figure 1 Amyloid deposition in Bielchowsky silver-stained sections of old mouse brains. Plaque deposition (indicated by arrows) is distributed throughout the brains of old/APP ${ }^{+}$mice, but is concentrated in the cortex, hippocampus $(A)$, and amygdala $(C)$, as compared with the same regions of the brains of old/APP ${ }^{-}$mice $(B$ and $D$, respectively). Young/APP ${ }^{-}$and young/APP ${ }^{+}$mice (data not shown) do not show any amyloid plaque deposition (magnification, 40x).

stimulus (CS) and the context in which that CS was paired with an aversive footshock unconditional stimulus (US). We also expected that old Tg2576 mice would be deficient at learning a contextual discrimination, a more difficult task that requires both the hippocampus and amygdala.

\section{RESULTS}

\section{Histology}

The photomicrograph in Figure 1 shows representative $A \beta$ plaque pathology in the hippocampus (Fig. 1A) and amygdala (Fig. 1B) of an old/APP ${ }^{+}$mouse brain stained with Bielchowsky silver. Numerous plaques were found throughout these brain structures, compared with respective areas of an old/APP ${ }^{-}$mouse brain (Figs. 1C,D). Young mice, regardless of genotype, were used as negative controls and displayed no $A \beta$ deposition (data not shown).

\section{Behavior}

All of the mice used in these experiments, regardless of age and genotype, displayed a healthy appearance and normal behavior (Hsiao et al. 1996). During food deprivation, some mice became ill, which was evident by changes in body temperature (mice were cold to the touch and shaking), posture (crouching), and activity (very few movements, which were slow and labored). None of these behaviors were evident when the mice were allowed ad libitum food access. Mice that became ill were given a solution of sucrose in water and placed on a heating pad, and in the most serious cases, given a small subcutaneous injection of lactated Ringers solution.

\section{Experiment 1: Rewarded Alternation in the T-Maze}

It has previously been shown that $\operatorname{Tg} 2576$ mice that overexpress hAPPswe are deficient at several hippocampus-dependent tasks (Hsiao et al. 1996; Chapman et al. 1999). In the first experiment, we attempted to replicate those studies that have shown a deficit among old Tg2576 mice in rewarded alternation in a T-maze task.

After a 4-d habituation period on the T-maze, mice were trained to alternate arm choices to receive a sucrose pellet reward. Training consisted of 6 trials per day for $14 \mathrm{~d}$. Acquisition of rewarded alternation was retarded in old/ $\mathrm{APP}^{+}$mice. In fact, none of the mice in the old $/ \mathrm{APP}^{+}$group reached the behavioral criterion of at least 5 out of 6 correct responses over three consecutive training days (Fig. 2). A Kruskall-Wallis test confirmed a significant difference in the rate at which the groups reached the criterion for learning the task $(H=12.2 ; p<0.01)$. Post hoc comparisons indicated that old $/ \mathrm{APP}^{+}$mice were significantly impaired relative to young and old/APP ${ }^{-}$mice, as well as young/APP ${ }^{+}$ mice, which did not differ from one another (Mann-Whitney $U, p<0.05)$. Latencies to choose an arm of the T-maze were collapsed across forced and free trials into 2-d blocks. Running speeds were similar across groups, as there were no significant group differences in latency to make an arm choice $\left(F_{(3,43)}<1\right.$; Fig. 3) trials. The results of this experiment support previous findings of age-related deficits in Tg2576 mice on a rewarded T-maze alternation task (Chapman et al. 1999). That the young/ $\mathrm{APP}^{+}$group was comprised entirely of female mice could suggest a sex effect between young/ $\mathrm{APP}^{+}$and old/APP ${ }^{+}$mice. However, there

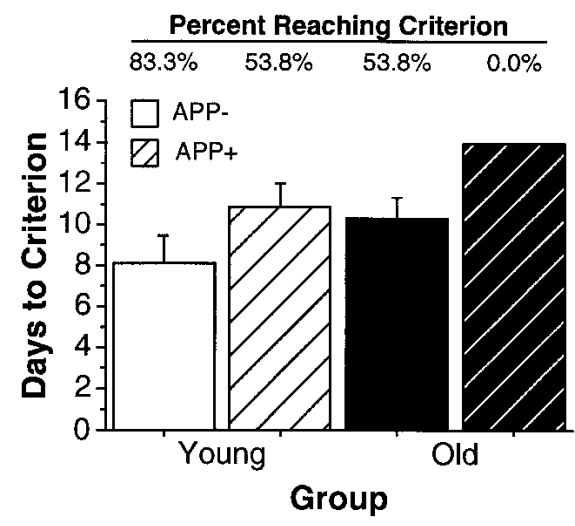

Figure $2 \mathrm{Old} / \mathrm{Tg}$ mice are deficient at learning a rewarded T-maze alternation task (Experiment 1). Mean \pm SEM number of days for each group to reach the criterion for learning of at least 5 out of 6 correct responses on 3 consecutive days. There were no differences among young/APP ${ }^{-}$(solid open bar), young/APP (hatched open bar), and old/APP ${ }^{-}$(solid filled bar) groups in days required to reach criterion, or in the percentage of animals in each group that reached criterion. None of the old/APP ${ }^{+}$mice (hatched filled bar) had reached criterion by the 14-d point, at which the experiment was stopped.

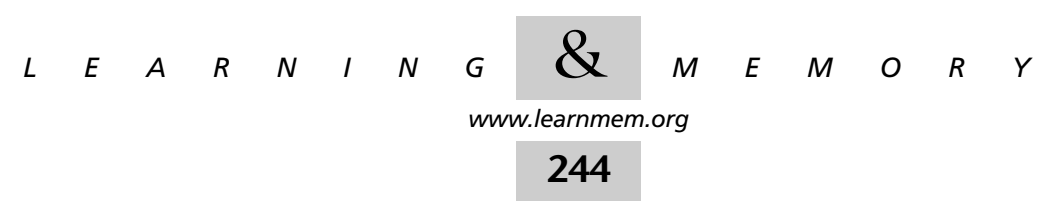




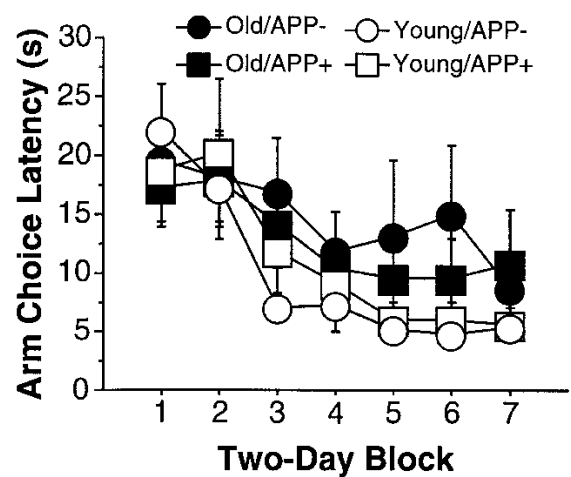

Figure 3 Arm choice latencies are similar across young and old $\mathrm{APP}^{+}$and $\mathrm{APP}^{-}$mice (Experiment 1). Mean \pm SEM latency (in seconds) to make an arm choice across the 14 training days (collapsed into 2-d blocks). There were no group differences in arm choice latencies, indicating no effects of age or transgene on gross motor abilities.

were no sex differences in learning rates either within any of the other groups or across all animals $(p>0.05)$.

\section{Experiment 2: Pavlovian Fear Conditioning}

Mice that overexpress hAPPswe show elevated levels of $A \beta 40$ and $A \beta 42$ along with $A \beta$ deposits in the cortex, hippocampus, and amygdala (Price et al. 1998). Although several studies have reported a deficiency among old Tg2576 mice in learning hippocampus-dependent tasks, it has yet to be shown if these same mice have difficulty in amygdaladependent tasks. To this end, we trained the mice used in Experiment 1 in a Pavlovian fear-conditioning task, which has been shown to be amygdala-dependent (Maren and Fanselow 1996; Maren 1999). The hippocampus also plays a role in fear conditioning to the places where aversive events occur, so-called contextual fear conditioning (Maren et al. 1998). Thus, we hypothesized that old $\mathrm{Tg} 2576$ mice, because of the deposition of amyloid plaques in the structures critical for learning Pavlovian conditional associations, would be deficient compared with old/APP ${ }^{-}$and young mice in conditional fear to both a discrete tone CS and to the context in which the CS was paired with an aversive footshock.

For Pavlovian fear conditioning, mice received 3 or 5 tone-footshock trials in a novel conditioning chamber. Conditional freezing to the conditioning context and to the tone CS are shown in Figures 4, A and B, respectively. Conditional freezing was not different among the groups receiving 3 or 5 CS-US pairings, and these data were collapsed. Inspection of Figure 4 reveals that old/APP ${ }^{+}$mice were not deficient in the acquisition of Pavlovian fear conditioning to either auditory or contextual CSs. In fact, old mice showed more conditional freezing than young mice. There was a significant main effect of age $\left(F_{(1,37)}=7.5 ; p<0.01\right)$ in levels of freezing to the conditioning context during retrieval testing (Fig. 4A), and Fisher's PLSD confirmed that old mice froze more during the retrieval test than young mice $(p$ $<0.05)$. Greater freezing among the old mice during context fear retention testing was probably nonassociative, insofar as old mice also showed greater levels of freezing prior to footshock on the conditioning day $\left(F_{(3,37)}=19.8\right.$; $p<0.0001$; data not shown). There were no group differences in retrieval of fear to the tone $\operatorname{CS}\left(F_{(3,37)}<1\right.$; Fig. 4B), and no age $\times$ genotype interactions in any of these effects $(F<1)$. Contrary to our hypotheses, old $\mathrm{Tg} 2576$ mice were unimpaired in acquiring auditory and contextual fear conditioning when compared with their littermate controls.

\section{Experiment 3: Decreased Context Salience and Pavlovian Fear Conditioning}

Our fear-conditioning experiment failed to elucidate an effect of hAPPswe overexpression in old mice on conditional
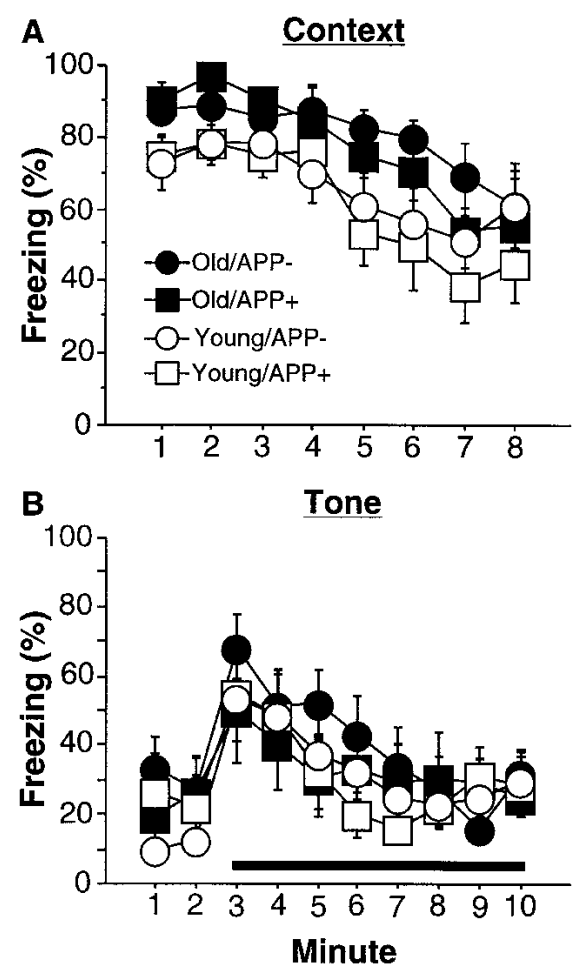

Figure 4 Amyloid deposition does not disrupt learning of conditional fear (Experiment 2). (A) Context test. Mean \pm SEM percentage freezing across the 8-min context retrieval test in context A. Contrary to expectations, old/APP ${ }^{+}$mice (filled squares) showed no deficits in conditional fear to the context in which fear conditioning had taken place $24 \mathrm{~h}$ prior as compared with young/APP- (open circles), young/ $\mathrm{APP}^{+}$(open squares), and old/APP- (filled circles) mice. $(B)$ Tone test. Mean \pm SEM percentage of freezing across the 10-min tone retrieval test. The continuous tone CS (horizontal bar) was turned on 2 min after the mice were placed in the testing chambers. Contrary to expectations, old/APP ${ }^{+}$mice showed no deficits in conditional fear to the tone CS when tested $48 \mathrm{~h}$ after fear conditioning took place as compared with young/APP ${ }^{-}$, young/APP ${ }^{+}$, and old/APP ${ }^{-}$mice.

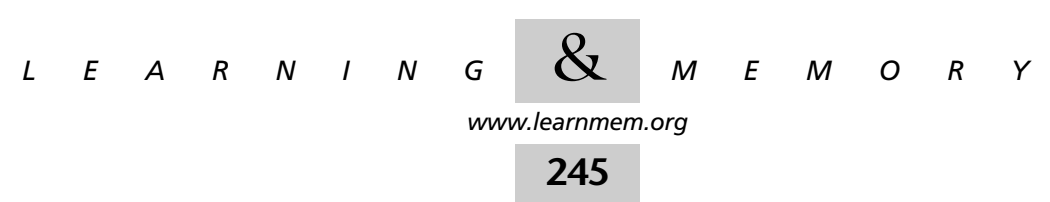


fear to either the training context or the tone CS. However, one recent report has shown impaired contextual fear learning in Tg2576 mice (Dineley et al. 2002). One potential source for this discrepancy is that the conditioning context used by Dineley and colleagues supported much less conditional fear than the context we used in Experiment 2. Moreover, auditory fear was much higher than contextual fear in the experiments reported by Dineley and colleagues. This indicates that their tone CS was more salient than the contextual CS. The difference in salience in these cues allowed the tone CS to overshadow the context CS (Rescorla and Wagner 1972; Odling-Smee 1978), resulting in a weaker context-US memory that may have been more easily disrupted by hippocampal pathology (Good and Honey 1991). We addressed this issue by fear-conditioning naive Tg2576 and wild-type mice in a context that produced less conditional and unconditional freezing than the training context in Experiment 2. We hypothesized that old $\mathrm{Tg} 2576$ mice would show impaired contextual fear conditioning when the context is overshadowed by the tone CS.

Mice were fear conditioned as before, except that the conditioning context was modified to reduce its salience. Conditional freezing to the conditioning context and to the tone CS are shown in Figure 5, A and B, respectively. A one-way ANOVA revealed a significant effect of genotype on retrieval of fear to the training context $\left(F_{(1,35)}=13\right.$; $p=0.001)$. Post hoc comparisons $(p \leq 0.05)$ indicated that $\mathrm{APP}^{+}$mice froze less to the conditioning context than $\mathrm{APP}^{-}$ mice (Fig. 5A). On the second testing day, there were no group differences in levels of freezing to the tone CS $(F<1$; Fig. 5B). As hypothesized, $\mathrm{APP}^{+}$mice showed impaired contextual conditioning compared with wild-type controls when the salience of the conditioning context was reduced. This deficit was not due to impaired performance of the freezing response, insofar as freezing to the auditory CS was normal.

\section{Experiment 4: Pavlovian Fear Conditioning- Context Discrimination}

Recent reports indicate that contextual fear conditioning can be acquired by rats with hippocampal lesions under some conditions (Maren et al. 1997; Frankland et al. 1998). Therefore, we also trained mice in a contextual discrimination, which has proved to be more hippocampal-dependent than standard contextual fear conditioning (Frankland et al. 1998; Antoniadis and McDonald 1999, 2000). We hypothesized that the old $\mathrm{Tg} 2576$ mice would show poor contextual discrimination.

In the contextual discrimination task, mice were placed in two distinct contexts each day; an unsignaled footshock was presented in one of these two contexts (no auditory cues were used). Context discrimination across the nine training days is shown in Figure 6. All mice acquired a
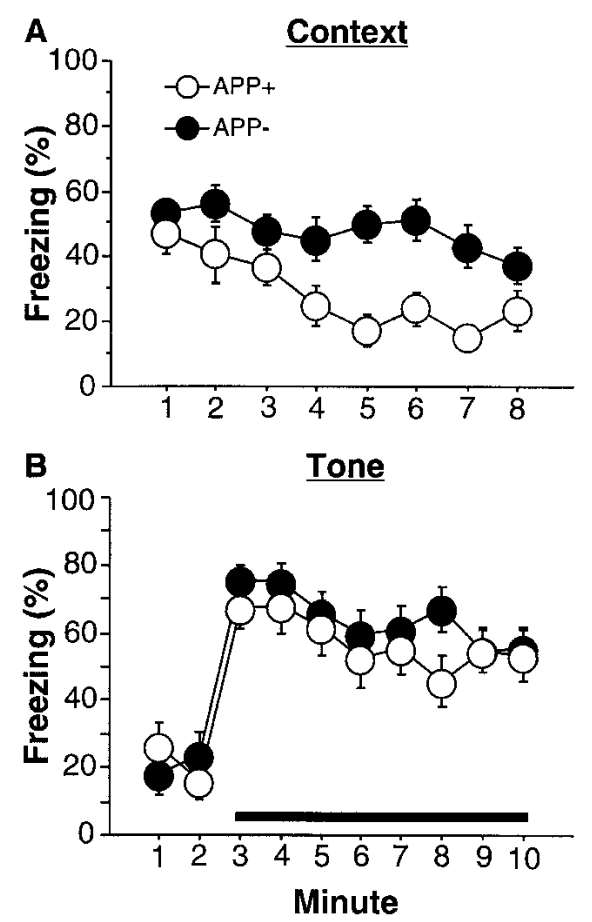

Figure 5 Amyloid deposition disrupts fear conditioning to the training context but not to the tone CS when context salience is decreased (Experiment 3). (A) Context test. Mean \pm SEM percentage freezing across the 8-min context retrieval test in context A. Old $\mathrm{APP}^{+}$mice (open circles) show less fear to the context in which fear conditioning had taken place $24 \mathrm{~h}$ prior than old/APP ${ }^{-}$mice (filled circles). (B) Tone test. Mean \pm SEM percentage of freezing across the 10-min tone retrieval test. The continuous tone CS (horizontal bar) was turned on 2 min after the mice were placed in the testing chambers. Old/APP ${ }^{+}$mice showed no deficits in conditional fear to the tone CS when tested $48 \mathrm{~h}$ after fear conditioning took place as compared with old/APP ${ }^{-}$mice.

significant contextual discrimination. This was confirmed by a significant context $\times$ day interaction in the ANOVA $\left(F_{(8,224)}=9.972 ; p<0.0001\right)$. There was not a significant effect of age or genotype or an interaction of these variables, indicating intact contextual discrimination in $\mathrm{APP}^{+}$ mice. To more easily compare discrimination across the groups, a difference score was calculated by subtracting freezing in the no-shock context from that in the shock context (Fig. 7). An analysis of these data revealed a significant interaction of age $\times$ training block $\left(F_{(2,56)}=3.9\right.$; $p<0.05$ ); Fisher's PLSD performed on the last 3-d block suggested that old mice were deficient at acquiring the discrimination $(p<0.05)$. However, there was no difference between old/APP ${ }^{+}$and old/APP ${ }^{-}$mice on this measure. The old mice appeared to generalize fear across the contexts, which minimized the difference score between freezing in the "shock" and "safe" contexts. Because neither group of old mice reliably discriminated between the contexts, a floor effect could account for the failure to detect a deficit in the old/APP ${ }^{+}$mice relative to the old/APP ${ }^{-}$mice. Never-

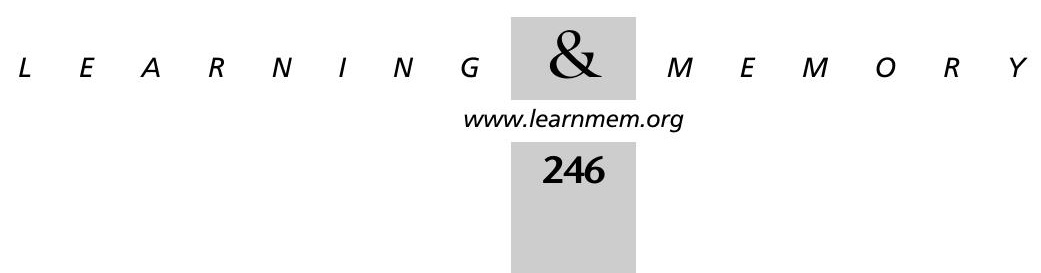



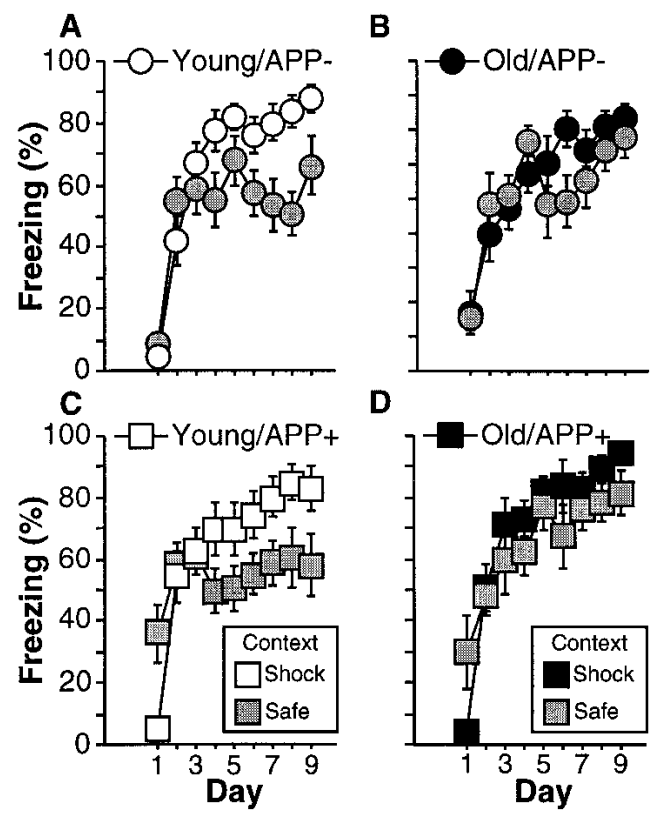

Figure 6 Old mice show less context discrimination than young mice (Experiment 4). Mean \pm SEM percentage freezing averaged across the 3-min preshock period in the shock (open/filled symbols) and safe (gray symbols) contexts on each of the nine training days. Whereas all mice conditioned to the shock context at the same rate and to the same extent, this fear was generalized more to the safe context among old animals $(B, D)$ than young animals $(A, C)$.

theless, it appears that hAPPswe overexpression does not impair the acquisition of a contextual discrimination.

\section{DISCUSSION}

In the present experiments, we aimed to further characterize the nature of the behavioral deficits in transgenic mice that overexpress hAPPswe. To this end, we tested Tg2576 mice on learning and memory tasks that require the hippocampus, amygdala, or both structures. Consistent with other reports, we found that Tg2576 mice showed a pronounced age-dependent deficit in the acquisition of rewarded alternation on a T-maze. This deficit was not caused by any obvious performance deficit in old $/ \mathrm{APP}^{+}$mice, as these mice showed choice latencies and motivations for reward that were similar to those of animals in the other groups. Interestingly, old $/ \mathrm{APP}^{+}$mice performed close to chance on choice trials-they did not perseverate responses. This indicates that their poor performance on the task was due to a deficit in spatial working memory and not due to a predisposition to return to previously visited places or repeat motor responses. The deficit in rewarded alternation was extreme-it was apparent even with a minimal delay between sample and choice trials.

Consistent with their deficits in spatial alternation, old Tg2576 mice also showed deficits in contextual fear conditioning under some conditions. Although these mice ac- quired context fear when the context was salient (Experiment 1 ) or the only signal for shock (Experiment 4), they were deficient in the acquisition of background contextual fear (Phillips and LeDoux 1994). That is, contextual fearconditioning deficits in old Tg2576 mice were apparent when a discrete tone CS overshadowed the contextual CS (Experiment 3). Importantly, Tg2576 mice were no different from wild-type controls in acquiring conditional fear to a tone CS. Collectively, this pattern of results indicates that pathology in the hippocampus, not the amygdala, is responsible for the contextual fear-conditioning deficits in $\mathrm{Tg} 2576$ mice.

These results replicate and extend a recent report that also shows contextual fear-conditioning deficits in old Tg2576 mice (Dineley et al. 2002). In this study, both 5- and 9-month-old Tg2576 mice showed impairments in contextual fear conditioning, and these impairments were overcome by additional training in the 5-month-old group but not in the 9-month-old group. Collectively, these results are consistent with the effects of hippocampal lesions on contextual fear conditioning in rats (Kim and Fanselow 1992; Phillips and LeDoux 1992), and indicate that amyloid plaque pathology in the hippocampus may mimic the effects of lesions on contextual fear conditioning in mice. Interestingly, contextual fear-conditioning deficits have only been shown in $\mathrm{Tg} 2576$ mice of intermediate age (5-14 mo). It is conceivable that, rather than being mediated by conditioning context salience, these deficits are age-dependent; that is, they are only apparent in middle-aged, but not young (2-4 mo) or old (16-18 mo) mice.

The pattern of behavioral deficits we have observed in mice may be related to the progression of pathology in AD patients. That is, in humans, it has been shown that the

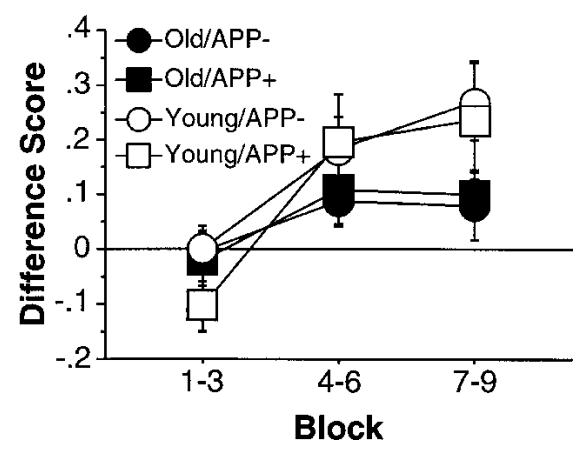

Figure 7 Amyloid deposition does not affect learning on a contextual discrimination task (Experiment 4). Mean \pm SEM difference scores (percentage freezing in shock context - percentage freezing in safe context) across the three 3-d blocks of context discrimination trials. Although old $/ \mathrm{APP}^{+}$mice (filled squares) were not different from old/APP ${ }^{-}$mice (filled circles), all old mice (filled symbols) were impaired at learning the discrimination as compared with the young mice (open symbols), which did not differ from one another. These results indicate that the deficiency among old mice in discriminating contexts is caused by overgeneralization of fear across contexts.

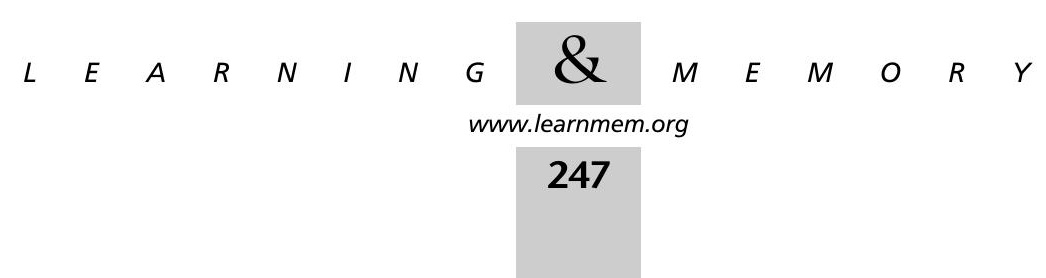


neuropathological effects of $\mathrm{AD}$ are first observed in the perforant path-dentate granule cell synapses (Braak and Braak 1991; Gómez-Isla et al. 1996). Additionally, AD pathology specifically disconnects the hippocampus with its cholinergic afferents (Gau et al. 2002) and efferent structures (Hyman et al. 1984; Grady et al. 2001). Because the hippocampus shows pathology before other brain structures, it is conceivable that hippocampal-dependent learning is more sensitive to disruption in $\mathrm{AD}$ than forms of learning that are mediated by other brain regions, regardless of the eventual amyloid deposition levels in these other brain regions. Whether alterations in synaptic plasticity (Chapman et al. 1999), excitotoxicity (Takahashi et al. 2000; Fitzjohn et al. 2001), or some other mechanism underlie the deficits in hippocampal learning is an issue that remains to be resolved.

Of course, $\mathrm{AD}$ is also associated with marked neuronal loss in the amygdala (Scott et al. 1991, 1992). In AD, damage to the amygdala and its associated cortex increases the severity of memory deficits attributable to hippocampal damage (Mori et al. 1997), and normal enhancement of memory for emotional compared with neutral stimuli is disrupted (Hamann et al. 2000; cf. Moayeri et al. 2000). Impairment of emotional event memory in $\mathrm{AD}$ patients is related to the intensity of amygdalar damage (Mori et al. 1999). Additionally, $\mathrm{AD}$ patients report a decreased affective response to pain (Scherder et al. 1999) as well as a decreased ability to detect fear in others' faces (Lavenu et al. 1999). Furthermore, fear conditioning to discrete conditional stimuli is impaired in AD patients (Hamann et al. 2002). These findings predict a deficit in emotional learning in old Tg2576 mice, which also show amygdaloid plaques, although these mice do not display the marked neuronal loss and neurofibrillary tangles characteristic of human AD (Irizarry et al. 1997; Turner 2001). Nonetheless, although the old/APP ${ }^{+}$ mice in our study had severe deficits in T-maze learning, they acquired auditory fear and some forms of contextual fear normally. This indicates that amygdala pathology in old $\operatorname{Tg} 2576$ mice is not sufficient to yield deficits in fear conditioning. Indeed, amygdala damage must be complete to observe fear-conditioning deficits (Maren 1998).

Although old Tg2576 mice show impaired contextual fear conditioning under some conditions (Experiment 3), they were capable of learning a contextual discrimination (Experiment 4) and freezing in a salient context (Experiment 2). In view of the parallel deficits in spatial alternation in these animals, our results reiterate others' suggestions that spatial working memory and contextual learning and memory may be mediated by different neural systems. Richmond et al. (1999) have reported that spatial learning and contextual conditioning are differentially sensitive to hippocampal lesions. Indeed, fear conditioning is much less reliant on cortical inputs to the hippocampus (Bannerman et al. 2001b) than spatial learning on the T-maze (Banner- man et al. 2001a). Our results provide another dissociation between spatial learning (rewarded alternation) and contextual fear conditioning.

In summary, the results of the present study confirm the learning and memory deficits that have previously been shown in transgenic mice overexpressing hAPPswe (Hsiao et al. 1996; Chapman et al. 1999; King et al. 1999). Deficits in spatial working memory in hAPPswe mice are consistent with the memory deficits reported in other rodent models of AD (Yamaguchi et al. 1991; Moran et al. 1995; Nalbantoglu et al. 1997; Sturchler-Pierrat et al. 1997; Morgan et al. 2000; Raber et al. 2000; Stéphan et al. 2001). Additionally, the deficits we have found in contextual fear conditioning mirror those reported in a recent study (Dineley et al. 2002). However, we have also found that old $\mathrm{Tg} 2576$ do not have a global deficit in contextual fear conditioning; they are only impaired when the context is overshadowed by a discrete CS. Surprisingly, we found no deficits in $\mathrm{Tg} 2576$ mice in auditory fear conditioning, despite the presence of dense amyloid plaque deposition in the amygdalae of aged Tg2576 mice. Therefore, further studies are necessary to fully understand the behavioral effects of amyloid neuropathology on learning and memory processes. Whereas tasks dependent on a functional hippocampus seem to be especially vulnerable to amyloid deposition, amygdala-dependent learning appears less sensitive. Further understanding of the behavioral effects of Alzheimer's disease and the neuropathology associated with it will lead us to more effective treatments for this devastating disease.

\section{MATERIALS AND METHODS}

\section{Experiment 1: Rewarded Alternation in the T-Maze}

\section{Subjects}

The subjects used in Experiments 1 and 2 were 57 C57B6/SJL mice. Breeding and histological methods were performed as previously described (Gau et al. 2002). Young (2-4 mo) and old (16-18 mo) transgenic (Tg2576; APP K670N/M671L; Hsiao et al. 1996) and wild-type (nontransgenic littermates) mice were used in this study, yielding the following groups $(\mathrm{M}=$ male; $\mathrm{F}=$ female; $\mathrm{APP}^{+}=\mathrm{Tg} 2576 ; \mathrm{APP}^{-}=$wild type $)$young $/ \mathrm{APP}^{-}(n=14 ; 3 \mathrm{M}, 11$ F), young $/ \mathrm{APP}^{+}(n=14 ; 0 \mathrm{M}, 14 \mathrm{~F})$, old $/ \mathrm{APP}^{-}(n=16 ; 6 \mathrm{M}, 10 \mathrm{~F})$, and old $/ \mathrm{APP}^{+}(n=13 ; 9 \mathrm{M}, 4 \mathrm{~F})$. After arrival, the mice were individually housed in opaque plastic (Nalgene) cages on a 14/10-h light/dark cycle (lights on at 7:00 a.m.) and allowed ad libitum access to food and water for $2 \mathrm{wk}$ prior to any behavioral testing. The experiments were performed in two replications, with different sets of mice for each replication, in a counterbalanced order. Mice received both T-maze training (Experiment 1) and fear conditioning (Experiment 2), although not all subjects completed both tasks. For the first replication, mice received T-maze training prior to fear conditioning; in the second replication, the order of the training procedures was reversed. Approximately $2 \mathrm{wk}$ elapsed between experiments within each replication. Because several mice died before completing both experiments, the number of subjects in each group for each experiment is different. 


\section{Behavioral Apparatus}

The mice were trained on a rewarded alternation task using a conventional T-maze. The maze was constructed of clear Plexiglas walls $(20 \mathrm{~cm}$ tall) and a black Plexiglas floor. The arms and stem of the $T$ were each $45 \mathrm{~cm}$ long by $10 \mathrm{~cm}$ wide. Clear Plexiglas guillotine doors were placed at the entrance to each of the arms. A third guillotine door was placed $10 \mathrm{~cm}$ from the base of the $\mathrm{T}$ and defined the start box. At the end of each of the goal arms was a small well into which food rewards ( $\approx 10$-mg sucrose pellets; Noyes, Inc.) were placed. The maze was mounted on a cart $(\approx 90 \mathrm{~cm}$ tall $)$ that was located in the center of the mouse colony room. Extramaze cues included the rack of mouse cages, a door, sink, and computer, the experimenter, and several posters on the walls.

\section{Procedure}

Before T-maze testing began, the mice were placed on a fooddeprivation schedule, in which food access was gradually reduced from $\approx 3.5 \mathrm{~g} / \mathrm{d}$ to $\approx 2.5 \mathrm{~g} / \mathrm{d}$ over $3 \mathrm{~d}$. Both young and old Tg2576 mice show a hypersensitive hypothalamic-pituitary-adrenal response to stressors such as restraint and food deprivation; in the case of the latter, this response often leads to severe hypoglycemia and mortality (Pedersen et al. 1999). Of the original 57 mice, 48 completed the T-maze training, in the following groups: young/ $\mathrm{APP}^{-}(n=12 ; 3 \mathrm{M}, 9 \mathrm{~F})$, young/APP $(n=13 ; 0 \mathrm{M}, 13 \mathrm{~F})$, old $/ \mathrm{APP}^{-}$ $(n=13 ; 4 \mathrm{M}, 9 \mathrm{~F})$, and old $/ \mathrm{APP}^{+}(n=10 ; 8 \mathrm{M}, 2 \mathrm{~F})$. The mice were given $4 \mathrm{~d}$ to habituate to the maze, in which they were allowed to explore the apparatus for $5 \mathrm{~min} / \mathrm{d}$ or until reward pellets scattered throughout the maze were all consumed. On each of the 14 training days, mice were run in squads of 3-4 and given 6 pairs of training trials. The first trial of each pair was a forced trial, in which one of the goal arm guillotine doors was closed and the mouse was constrained to selecting the opposite arm; the order of forced choices was pseudorandomly selected so that each mouse was forced to traverse each arm three times per day, but on no more than two trials in a row were they forced down the same arm. The mouse was returned to the start box $15-20 \mathrm{sec}$ after consuming the reward. On the second, or free-choice trial, both goal arm doors were opened, but only the arm opposite the one selected in the forced trial was baited. Latency to make an arm choice from the time the start box guillotine door was opened was also recorded during the free and forced trials. The criterion for a mouse having learned the rewarded alternation task was 3 consecutive days of at least 5 correct responses out of the 6 free trials (Chapman et al. 1999). For example, a mouse that correctly alternated on 5 out of 6 free trials on training days 5, 6, and 7 was given a value of 7 . Training on the T-maze lasted for $14 \mathrm{~d}$. After the completion of the T-maze learning task, the mice were returned to ad libitum food and water availability for at least $2 \mathrm{wk}$ prior to any further experimental testing or sacrifice.

\section{Data Analysis}

Mice that did not reach criterion before training was terminated were assigned a score of 14 for days to reach criterion. Nonparametric statistics were used to analyze these data. A Kruskall-Wallis test was performed on the average number of days the mice in each group took to reach criterion performance. After a significant $H$ value was found, post hoc comparisons in the form of Mann-Whitney $U$ were performed. Also reported is the percentage of mice from each group that reached the criterion level of performance. An ANOVA was performed on the latencies to make an arm choice after the start of each trial over the course of training for both forced and free trials. All data are presented as means \pm SEMs.

\section{Experiment 2: Pavlovian Fear Conditioning}

\section{Subjects}

Of the 57 mice at the beginning of the experiment, a total of 49 survived to the end of the fear-conditioning procedure, in the following groups: old/APP ${ }^{+}(n=9 ; 8 \mathrm{M}, 1 \mathrm{~F})$, young/ $\mathrm{APP}^{+}(n=14 ; 0$ $\mathrm{M}, 14 \mathrm{~F})$, young/APP $(n=13 ; 3 \mathrm{M}, 10 \mathrm{~F})$, and old $/ \mathrm{APP}^{-}(n=13 ; 4$ M, 9 F). The mice were housed as described in Experiment 1 and were maintained on ad libitum food and water access throughout this experiment.

\section{Behavioral Apparatus}

Fear conditioning took place in four identical observation chambers $(30 \times 24 \times 21 \mathrm{~cm}$; MED-Associates, Inc.). The chambers were constructed from aluminum (sidewalls) and Plexiglas (rear wall, ceiling, and hinged front door) and were situated in sound-attenuating cabinets located in a brightly lit and isolated room. The floor of each chamber consisted of 36 stainless steel rods $(3 \mathrm{~mm}$ in diameter) spaced $8 \mathrm{~mm}$ apart (center-to-center). Rods were wired to a shock source and solid-state grid scrambler (MED-Associates, Inc.) for the delivery of footshock USs. A speaker mounted outside a grating in one wall of the chamber was used for the delivery of acoustic CSs. A 15-W house light was mounted on the opposite wall. The chambers were cleaned with a 5\% ammonium hydroxide solution, and stainless steel pans containing a thin film of the same solution were placed underneath the grid floors to provide a distinct odor before the mice were placed inside. Ventilation fans in each cabinet supplied background noise ( $65 \mathrm{~dB}$; A scale). This chamber configuration is subsequently referred to as context $\mathrm{A}$.

\section{Procedure}

Mice were conditioned and then tested for fear to the conditioning context and to the tone CS on the two subsequent days. For fear conditioning, mice were transported in squads of 2-4 (counterbalanced for age and genotype) and placed in the conditioning chambers; the chamber position was counterbalanced for each squad. The mice received 3 or 5 tone $(10 \mathrm{sec}, 5 \mathrm{kHz}, 85 \mathrm{~dB})$-footshock $(0.5 \mathrm{sec}, 0.5 \mathrm{~mA})$ trials (74-sec intertrial interval) beginning $128 \mathrm{sec}$ after being placed in the chambers. Sixty-four seconds after the final shock, the mice were returned to their home cages.

Twenty-four hours after the conditioning session, the mice were returned to the conditioning chambers in squads of 2-4 animals and tested for fear to the context in which they had received the tone-footshock trials. This test for fear to the context lasted $512 \mathrm{sec}$, after which the mice were returned to their home cages.

Twenty-four hours after the context test, the mice were tested for fear to the tone CS in context B. This context consisted of the same chambers used for context $\mathrm{A}$; however, the room lights and chamber houselights were turned off (three $40-\mathrm{W}$ red lights provided illumination). In addition, the doors on the sound-attenuating cabinets were closed, the ventilation fans were turned off, and the chambers were cleaned with a $1 \%$ acetic acid solution. To provide a distinct odor, stainless steel pans containing a thin film of acetic acid were placed underneath the grid floors before the mice were placed inside. In this context, the mice received a single continuous tone ( $512 \mathrm{sec}, 5 \mathrm{kHz}, 85 \mathrm{~dB}$ ) beginning $128 \mathrm{sec}$ after being placed in the chambers.

Fear to the context and to the tone CS was assessed by measuring freezing behavior (Maren 1998). The output from video cameras mounted above each chamber was fed into a video processor (Robot), and the mice were videotaped throughout each of the sessions. Freezing behavior, defined as the absence of all movement

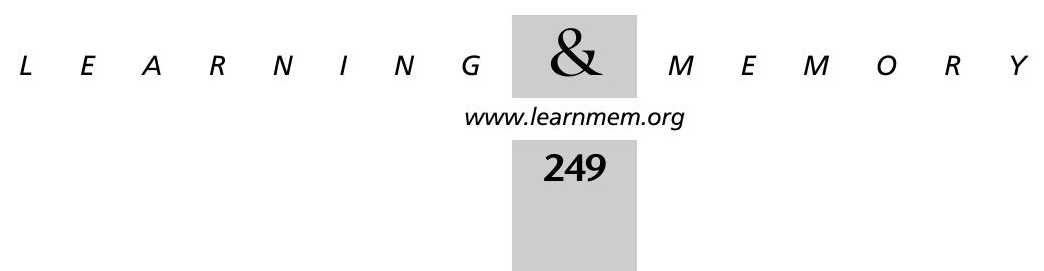


except for that necessitated by breathing, was scored using a timesampling procedure by an experimenter who was blind to the ages and genotypes of the mice. Measurements were made every $8 \mathrm{sec}$ for each mouse, yielding 64 observations during the 512-sec test. Freezing was quantified by computing the percentage of observations in which the mouse had been scored as freezing during the test. Approximately $2 \mathrm{wk}$ passed between fear-conditioning testing and any further behavioral testing or sacrifice.

\section{Histology}

Approximately $2 \mathrm{wk}$ after the completion of all behavioral testing, the mice were killed by cervical dislocation, and their brains were removed and hemisected saggitally. The right half of each brain was fixed in $4 \%$ paraformaldehyde in phosphate-buffered saline (PBS), $\mathrm{pH} 7.4$, at $4^{\circ} \mathrm{C}$ and processed for paraffin embedding. The paraformaldehyde-fixed hemibrains were sectioned coronally at 5-8 $\mu \mathrm{m}$ thickness, and sections were processed for hematoxylin and eosin, Bielchowsky silver, and Congo Red staining.

\section{Data Analysis}

For each session, the freezing data were transformed to a percentage of total observations, a probability estimate that is amenable to analysis with parametric statistics. These probability estimates of freezing were analyzed using ANOVA. Post hoc comparisons in the form of Fisher's PLSD tests were performed after a significant omnibus $F$ ratio. All data are represented as means \pm SEMs.

\section{Experiment 3: Decreased Context Salience And Pavlovian Fear Conditioning}

\section{Subjects}

The subjects were 37 naive mice obtained and housed as described in Experiment 1. At the beginning of training, all mice were 12-14 months old. The two groups were: $\operatorname{APP}^{+}(n=15 ; 7 \mathrm{M}, 8 \mathrm{~F})$ and $\mathrm{APP}^{-}(n=22 ; 8 \mathrm{M}, 14 \mathrm{~F})$. Throughout this experiment, the mice were maintained on an ad libitum regimen of food and water availability.

\section{Behavioral Apparatus}

The apparatus used in this experiment was identical to that used in Experiment 2, except that the $1 \%$ acetic acid solution was used to clean and provide a distinct odor in context $\mathrm{A}$ and a $1 \%$ ammonium hydroxide solution was used in context $\mathrm{B}$.

\section{Procedure}

The mice were fear conditioned as described in Experiment 2. All mice received 3 tone-shock pairings in context A. Testing for fear to the conditioning context and to the tone CS was performed on the two subsequent days as described in Experiment 2.

\section{Histology}

After behavioral testing, all mice were retained for further testing. Therefore, we have no histological data for these mice.

\section{Data Analysis}

Freezing behavior was measured and analyzed as described in Experiment 2 .

\section{Experiment 4: Pavlovian Fear Conditioning- Context Discrimination}

\section{Subjects}

The subjects were 32 naive mice obtained and housed as described in Experiment 1. At the beginning of training, young mice were 2.5 months old and the old mice were 17 months old. The four groups were: young/ $\mathrm{APP}^{-}(n=8 ; 4 \mathrm{M}, 4 \mathrm{~F})$, young/ $\mathrm{APP}^{+}(n=8 ; 4 \mathrm{M}, 4 \mathrm{~F})$, old $/ \mathrm{APP}^{-}(n=9 ; 5 \mathrm{M}, 4 \mathrm{~F})$, and old $/ \mathrm{APP}^{+}(n=7 ; 5 \mathrm{M}, 2 \mathrm{~F})$. Throughout this experiment, the mice were maintained on an ad libitum regimen of food and water availability.

\section{Behavioral Apparatus}

The apparatus used in this experiment was identical to that used in Experiment 2. In Experiment 2, we observed high levels of freezing among old animals in context A prior to any fear conditioning, which could possibly have resulted from some nonassociative fear to this context (in context $\mathrm{B}$ there was relatively little freezing before the tone CS was presented). To mitigate this effect, and to equate the salience of the two contexts, the configurations of contexts A and B were adjusted. After these changes, context A consisted of the conditioning chambers with grid floors placed in sound-attenuating cabinets. The chambers were lit by a $15-\mathrm{W}$ houselight, and ventilation fans provided background noise. Instead of ammonium hydroxide, a $70 \%$ ethanol solution was used to clean the cages and provide the distinct odor. In context $\mathrm{B}$, the same conditioning chambers were used. However, the red lights were no longer used, and the houselights in the chambers were turned on. The ventilation fans and room lights remained off, and the $1 \%$ acetic acid solution was used to clean the chambers and provide a distinct odor.

\section{Procedure}

On each of $9 \mathrm{~d}$, the mice were brought in squads of 4 (counterbalanced for age and genotype) and spent $256 \mathrm{sec}$ in both context A and context $\mathrm{B}$; the order of context exposure was counterbalanced. In context $\mathrm{A}$, half of the squads received a single footshock (1 sec, $0.75 \mathrm{~mA}) 192 \mathrm{sec}$ after being placed in the chambers, whereas the other half received the shock in context B. In the "safe" (no shock) context, the mice were simply exposed to the context for $256 \mathrm{sec}$. Approximately $4 \mathrm{~h}$ elapsed between placement in the two contexts each day.

\section{Histology}

Histological verification of amyloid plaques was performed as described in Experiment 2.

\section{Data Analysis}

Freezing behavior was measured and analyzed as described in Experiment 2. In this experiment, percentage of time spent freezing in the safe context was subtracted from percentage of time spent freezing in the shock context, yielding a difference score that was used as an index of discrimination between the two contexts. Difference scores were collapsed into 3-d blocks, and an ANOVA was performed on the blocked data. Post hoc comparisons in the form of Fisher's PLSD were performed after a significant omnibus $F$ ratio was observed.

\section{ACKNOWLEDGMENTS}

This research was supported by a grant from NIMH (MH57865) and a pilot grant from the Michigan Alzheimer's Disease Research Center (AG08671) to Stephen Maren. Kevin A. Corcoran is an NSF 
Graduate Research fellow. The authors thank Pavani Guntur, Joy Limpuangthip, and Omry MaOz for technical assistance.

The publication costs of this article were defrayed in part by payment of page charges. This article must therefore be hereby marked "advertisement" in accordance with 18 USC section 1734 solely to indicate this fact.

\section{REFERENCES}

Antoniadis, E.A. and McDonald, R.J. 1999. Discriminative fear conditioning to context expressed by multiple measures of fear in the rat. Behav. Brain Res. 101: 1-13.

. 2000. Amygdala, hippocampus and discriminative fear conditioning to context. Behav. Brain Res. 108: 1-19.

Ashe, K.H. 2001. Learning and memory in transgenic mice modeling Alzheimer's disease. Learn. Mem. 8: 301-308.

Bannerman, D.M., Yee, B.K., Lemaire, M., Wilbrecht, L., Jarrard, L., Iversen, S.D., Rawlins, J.N., and Good, M.A. 2001a. The role of the entorhinal cortex in two forms of spatial learning and memory. Exp. Brain Res. 141: 281-303.

Bannerman, D.M., Yee, B.K., Lemaire, M., Jarrard, L., Iversen, S.D. Rawlins, J.N., and Good, M.A. 2001b. Contextual fear conditioning is disrupted by lesions of the subcortical, but not entorhinal, connections to the hippocampus. Exp. Brain Res. 141: 304-311.

Braak, H. and Braak, E. 1991. Neuropathological staging of Alzheimer related changes. Acta Neuropathol. 82: 239-259.

Chapman, P.F., White, G.L., Jones, M.W., Cooper-Blacketer, D., Marshall, V.J., Irizarry, M., Younkin, L., Good, M.A., Bliss, T.V.P., Hyman, B.T., et al. 1999. Impaired synaptic plasticity and learning in aged amyloid precursor protein transgenic mice. Nat. Neurosci. 2: 271-276.

Chapman, P.F., Falinska, A.M., Knevett, S.G., and Ramsay, M.F. 2001. Genes, models, and Alzheimer's disease. Trends Genet. 17: 254-261.

Dineley, K.T., Xia, X., Bui, D., Sweatt, J.D., and Zheng, H. 2002. Accelerated plaque accumulation, associative learning deficits and up-regulation of $\alpha 7$ nicotinic receptor protein in transgenic mice co-expressing mutant human presenilin 1 and amyloid precursor proteins. J. Biol. Chem. 277: 22768-22780.

Fitzjohn, S.M., Morton, R.A., Kuenzi, F., Rosahl, T.W., Shearman, M., Lewis, H., Smith, D., Reynolds, D.S., Davies, C.H., Collingridge, G.L., et al. 2001. Age-related impairment of synaptic transmission but normal long-term potentiation in transgenic mice that overexpress the human APP695SWE mutant form of amyloid precursor protein. J. Neurosci. 21: 4691-4698.

Frankland, P.W., Cestari, V., Filipkowski, R.K., McDonald, R.J., and Silva, A.J. 1998. The dorsal hippocampus is essential for context discrimination but not for contextual conditioning. Behav. Neurosci. 112: $863-874$.

Frautschy, S.A., Yang, F., Irrizarry, M., Hyman, B., Saido, T.C., Hsiao, K., and Cole, G.M. 1998. Microglial response to amyloid plaques in APPsw transgenic mice. Am. J. Pathol. 152: 307-317.

Gau, J.-T., Steinhilb, M.L., Kao, T.-C., D'Amato, C.J., Gaut, J.R., Frey, K.A., and Turner, R.S. 2002. Stable $\beta$-secretase activity and presynaptic cholinergic markers during progressive CNS amyloidogenesis in Tg2576 mice. Am. J. Pathol. 160: 731-738.

Gómez-Isla, T., Price, J.L., McKeel Jr., D.W., Morris, J.C., Growdon, J.H., and Hyman, B.T. 1996. Profound loss of layer II entorhinal cortex neurons occurs in very mild Alzheimer's disease. J. Neurosci. 16: 4491-4500.

Good, M.A. and Honey, R.C. 1991. Conditioning and contextual retrieval in hippocampal rats. Behav. Neurosci. 105: 499-509.

Grady, C.L., Furey, M.L., Pietrini, P., Horwitz, B., and Rapoport, S.I. 2001. Altered brain functional connectivity and impaired short-term memory in Alzheimer's disease. Brain 124: 739-756.

Hamann, S.B., Monarch, E.S., and Goldstein, F.C. 2000. Memory enhancement for emotional stimuli is impaired in early Alzheimer's disease. Neuropsychology 14: 82-92.

. 2002. Impaired fear conditioning in Alzheimer's disease. Neuropsychologia 40: 1187-1195.
Hopper, M.W. and Vogel, F.S. 1976. The limbic system in Alzheimer's disease: A neuropathologic investigation. Am. J. Pathol. 85: 1-20.

Hsiao, K., Chapman, P., Nilsen, S., Eckman, C., Harigaya, Y., Younkin, S., Yang, F., and Cole, G. 1996. Correlative memory deficits, A $\beta$ elevation, and amyloid plaques in transgenic mice. Science 274: 99-102.

Hyman, B.T., Van Hoesen, G.W., Damasio, A.R., and Barnes, C.L. 1984. Alzheimer's disease: Cell specific pathology isolates the hippocampal formation in Alzheimer's disease. Science 225: 1168-1170.

Hyman, B.T., Van Hoesen, G.W., and Damasio, A.R. 1990. Memory-related systems in Alzheimer's disease: An anatomic study. Neurology 40: $1721-1730$.

Irizarry, M.C., McNamara, M., Fedorchak, K., Hsiao K., and Hyman, B.T. 1997. APPSw transgenic mice develop age-related A $\beta$ deposits and neuropil abnormalities, but no neuronal loss in CA1. J. Neuropathol. Exp. Neurol. 56: 965-973.

Kim, J.J. and Fanselow, M.S. 1992. Modality-specific retrograde amnesia of fear. Science 256: 675-677.

King, D.L., Arendash, G.W., Crawford, F., Sterk, T., Menendez, J., and Mullan, M.J. 1999. Progressive and gender-dependent cognitive impairment in the $\mathrm{APP}_{\mathrm{Sw}}$ transgenic mouse model for Alzheimer's disease. Behav. Brain Res. 103: 145-162.

Lavenu, I., Pasquier, F., Lebert, F., Petit, H., and Van der Linden, M. 1999 Perception of emotion in frontotemporal dementia and Alzheimer disease. Alzheimer Dis. Assoc. Disord. 13: 96-101.

Maren, S. 1998. Overtraining does not mitigate contextual fear conditioning deficits produced by neurotoxic lesions of the basolateral amygdala. J. Neurosci. 18: 3088-3907.

- 1999. Neurotoxic basolateral amygdala lesions impair learning and memory but not the performance of conditional fear in rats. $J$. Neurosci. 19: 8696-8703.

Maren, S. and Fanselow, M.S. 1996. The amygdala and fear conditioning: Has the nut been cracked? Neuron 16: 237-240.

Maren, S., Aharonov, G., and Fanselow, M.S. 1997. Neurotoxic lesions of the dorsal hippocampus and Pavlovian fear conditioning in rats. Behav. Brain Res. 88: 261-274.

Maren, S., Anagnostaras, S.G., and Fanselow, M.S. 1998. The startled seahorse: Is the hippocampus necessary for contextual fear conditioning? Trends Cog. Sci. 2: 39-42.

Matsuoka, Y., Picciano, M., La Francois, J., and Duff, K. 2001. Fibrillar $\beta$-amyloid evokes oxidative damage in a transgenic mouse model of Alzheimer's disease. Neuroscience 104: 609-613.

Moayeri, S.E., Cahill, L., Jin, Y., and Potkin, S.G. 2000. Relative sparing of emotionally influenced memory in Alzheimer's disease. Neuroreport 11: 653-655.

Moran, P.M., Higgins, L.S., Cordell, B., and Moser, P.C. 1995. Age-related learning deficits in transgenic mice expressing the 751-amino acid isoform of human $\beta$-amyloid precursor protein. Proc. Natl. Acad. Sci. 92: 5341-5345.

Morgan, D., Diamond, D.M., Gottschall, P.E., Ugen, K.E., Dickey, C., Hardy, J., Duff, K., Jantzen, P., DiCarlo, G., Wilcock, D., et al. 2000. $A \beta$ peptide vaccination prevents memory loss in an animal model of Alzheimer's disease. Nature 408: 982-985.

Mori, E., Yoneda, Y., Yamashita, H., Hirono, N., Ikeda, M., and Yamadori, A. 1997. Medial temporal structures relate to memory impairment in Alzheimer's disease: An MRI volumetric study. J. Neurol. Neurosurg. Psychiat. 63: 214-221.

Mori, E., Ikeda, M., Hirono, N., Kitagaki, H., Imamura, T., and Shimomura, T. 1999. Amygdalar volume and emotional memory in Alzheimer's disease. Am. J. Psychiatry 156: 216-222.

Nalbantoglu, J., Tirado-Santiago, G., Lahsaïni, A., Poirier, J., Goncalves, O. Verge, G., Momoli, F., Welner, S.A., Massicotte, G., Julien, J.-P., et al. 1997. Impaired learning and LTP in mice expressing the carboxy terminus of the Alzheimer amyloid precursor protein. Nature 387: 500-505.

Näslund, J., Haroutunian, V., Mohs, R., Davis, K.L., Davies, P., Greengard, P., and Buxbaum, J.D. 2000. Correlation between elevated levels of amyloid $\beta$-peptide in the brain and cognitive decline. J. Am. Med. Assoc. 283: 1571-1577.

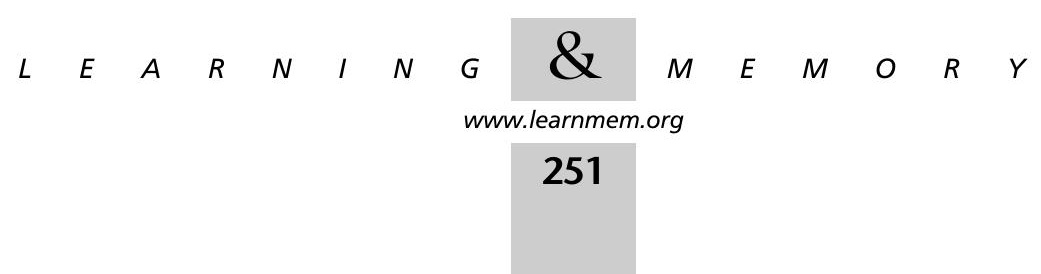


Odling-Smee, F.J. 1978. The overshadowing of background stimuli by an informative VS in aversive Pavlovian conditioning with rats. Anim. Learn. Behav. 6: 43-51.

Pappolla, M.A., Chyan, Y.J., Omar, R.A., Hsiao, K., Perry, G., Smith, M.A., and Bozner, P. 1998. Evidence of oxidative stress and in vivo neurotoxicity of $\beta$-amyloid in a transgenic mouse model of Alzheimer's disease: A chronic oxidative paradigm for testing antioxidant therapies in vivo. Am. J. Pathol. 152: 871-877.

Pedersen, W.A., Culmsee, C., Ziegler, D., Herman, J.P., and Mattson, M.P. 1999. Aberrant stress response associated with severe hypoglycemia in a transgenic mouse model of Alzheimer's disease. J. Mol. Neurosci. 13: 159-165.

Phillips, R.G. and LeDoux, J.E. 1992. Differential contribution of amygdala and hippocampus to cued and contextual fear conditioning. Behav. Neurosci. 106: 274-285.

-1994. Lesions of the dorsal hippocampal formation interfere with background but not foreground contextual fear conditioning. Learn. Mem. 1: 34-44.

Price, D.L., Tanzi, R.E., Borchelt, D.R., and Sisodia, S.S. 1998. Alzheimer's disease: Genetic studies and transgenic models. Ann. Rev. Genet. 32: 461-493.

Raber, J., Wong, D., Yu, G.-Q., Buttini, M., Mahley, R., Pitas, R.E., and Mucke, L. 2000. Apolipoprotein E and cognitive performance. Nature 404: 352-354.

Rescorla, R.A. and Wagner, A.R. 1972. A theory of Pavlovian conditioning: Variations in the effectiveness of reinforcement and nonreinforcement In Classical conditioning II: Current research and theory (eds. A.H Black and W.F. Prokasy), pp. 64-99. Appleton-Century-Crofts, New York.

Richmond, M.A., Yee, B.K., Pouzet, B., Veenman, L., Rawlins, J.N., Feldon, J., and Bannerman, D.M. 1999. Dissociating context and space within the hippocampus: Effects of complete, dorsal, and ventral excitotoxic hippocampal lesions on conditioned freezing and spatial learning. Behav. Neurosci. 113: 1189-1203.

Scherder, E., Bouma, A., Borkent, M., and Rahman, O. 1999. Alzheimer patients report less pain intensity and pain affect than non-demented elderly. Psychiatry 62: 265-272.

Scott, S.A., DeKosky, S.T., and Scheff, S.W. 1991. Volumetric atrophy of the amygdala in Alzheimer's disease: Quantitative and serial reconstruction. Neurology 41: 351-356.

Scott, S.A., DeKosky, S.T., Sparks, D.L., Knox, C.A., and Scheff, S.W. 1992. Amygdala cell loss and atrophy in Alzheimer's disease. Ann. Neurol. 32: $555-563$
Selkoe, D.J. 1998. The cell biology of $\beta$-amyloid precursor protein and presenilin in Alzheimer's disease. Trends Cell Biol. 8: 447-453. . 2000. The origins of Alzheimer disease: A is for amyloid. J. Am. Med. Assoc. 283: 1615-1617.

. 2001. Alzheimer's disease-Genotypes, phenotype, and treatments. Science 275: 630-631.

Smith, M.A., Hirai, K., Hsiao, K., Pappolla, M.A., Harris, P.L., Siedlak, S.L., Tabaton, M., and Perry, G. 1998. Amyloid- $\beta$ deposition in Alzheimer transgenic mice is associated with oxidative stress. J. Neurochem. 70: 2212-2215.

Steinhilb, M.L., Turner, R.S., and Gaut, J.R. 2001. The protease inhibitor, MG132, blocks maturation of the amyloid precursor protein Swedish mutant preventing cleavage by $\beta$-secretase. J. Biol. Chem. 276: 4476-4484

Stéphan, A., Laroche, S., and Davis, S. 2001. Generation of aggregated $\beta$-amyloid in the rat hippocampus impairs synaptic transmission and plasticity and causes memory deficits. J. Neurosci. 21: 5703-5714

Sturchler-Pierrat, C., Abramowski, D., Duke, M., Wiederhold, K.H., Mistl, C., Rothacher, S., Ledermann, B., Burki, K., Frey, P., Paganetti, P.A., et al. 1997. Two amyloid precursor protein transgenic mouse models with Alzheimer disease-like pathology. Proc. Natl. Acad. Sci. 94: 13287-13292.

Takahashi, M., Dore, S., Ferris, C.D., Tomita, T., Sawa, A., Wolosker, H., Borchelt, D.R., Iwatsubo, T., Kim, S.H., Thinakaran, G., et al. 2000. Amyloid precursor proteins inhibit heme oxygenase activity and augment neurotoxicity in Alzheimer's disease. Neuron 28: 461-473.

Terai, K., Iwai, A., Tasaki, Y., Watanabe, T., Miyata, K., and Yamaguchi, T. 2001. $\beta$-Amyloid deposits in transgenic mice expressing human $\beta$-amyloid precursor protein have the same characteristics as those in Alzheimer's disease. Neuroscience 104: 299-310.

Tomidokoro, Y., Harigaya, Y., Matsubara, E., Ikeda, M., Kawarabayashi, T. Okamoto, K., and Shoji, M. 2000. Impaired neurotransmitter systems by $A \beta$ amyloidosis in APPsw transgenic mice overexpressing amyloid $\beta$ protein precursor. Neurosci. Lett. 292: 155-158.

Turner, R.S. 2001. Alzheimer's disease in man and transgenic mice: Females at higher risk. Am. J. Pathol. 158: 797-801.

Yamaguchi, F., Richards, S.J., Beyreuther, K., Salbaum, M., Carlson, G.A., and Dunnett, S.B. 1991. Transgenic mice for the amyloid precursor protein 695 isoform have impaired spatial memory. Neuroreport 2: $781-784$.

Received June 6, 2002; accepted in revised form August 14, 2002. 


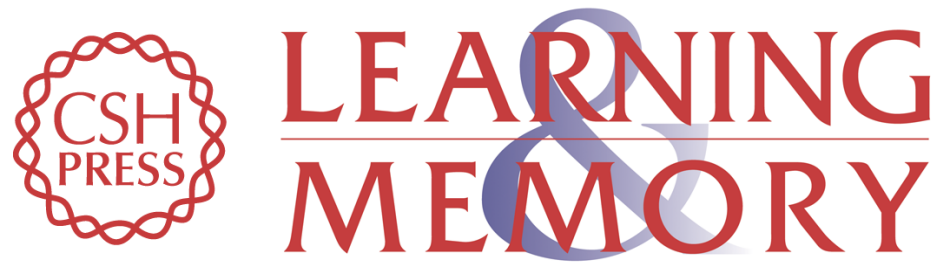

Overexpression of hAPPswe Impairs Rewarded Alternation and Contextual Fear Conditioning in a Transgenic Mouse Model of Alzheimer's Disease

Kevin A. Corcoran, Ye Lu, R. Scott Turner, et al.

Learn. Mem. 2002, 9:

Access the most recent version at doi: $10.1101 / \mathrm{lm} .51002$

References This article cites 61 articles, 18 of which can be accessed free at:

http://learnmem.cshlp.org/content/9/5/243.full.html\#ref-list-1

License

Email Alerting Receive free email alerts when new articles cite this article - sign up in the box at the Service top right corner of the article or click here. 